\title{
THE SYSTEM OF AUTOMATIC DETECTION OF PENETRATION THROUGH THE PROTECTED PERIMETER BASED ON FIBER OPTIC SENSORS AND NEURAL NETWORK
}

\author{
A.A. Fartukov, Xaker.cahek@gmail.com, \\ V.P. Shumeyko, ShumeikoVP@gmail.com, \\ L.S. Kazarinov, aiu@susu.ru \\ South Ural State University, Chelyabinsk, Russian Federation
}

\begin{abstract}
The article discusses the principle of constructing the software part of the alarm system's signal processing unit, which will solve the problem of detecting penetration through the protected perimeter by means of a signal coming from a sensitive optical fiber located on a mesh fence. The study is conducted through consideration of such problems as the decomposition of the signal received from a sensitive fiber-optic sensor into components and its further processing, first for training the neural network, and then for analyzing its state. A large part of the work is occupied by consideration of a solution that allows to form an algorithm for building a digital signal processing unit using a neural network and also to reduce the number of false alarms caused by interference and external influence on the security system.
\end{abstract}

Keywords: neural network, sensitive optical fiber, security system, signal processing unit.

\section{Introduction}

At present, due to the growth of the scale of criminal and terrorist threats, measures are being taken to strengthen the protection of important and especially important sites. These measures are ultimately aimed at tightening the requirements for perimeter security systems, which are designed to ensure the security of the protected facility. The systems, as a rule, are located along the perimeter of the protected facility and provide the "early" alarm signal generation necessary for the timely and effective response of the security forces to the invasion [1].

\section{Description of modules}

The installation scheme for perimetral security alarms on the basis of fiber is shown in Fig. 1.

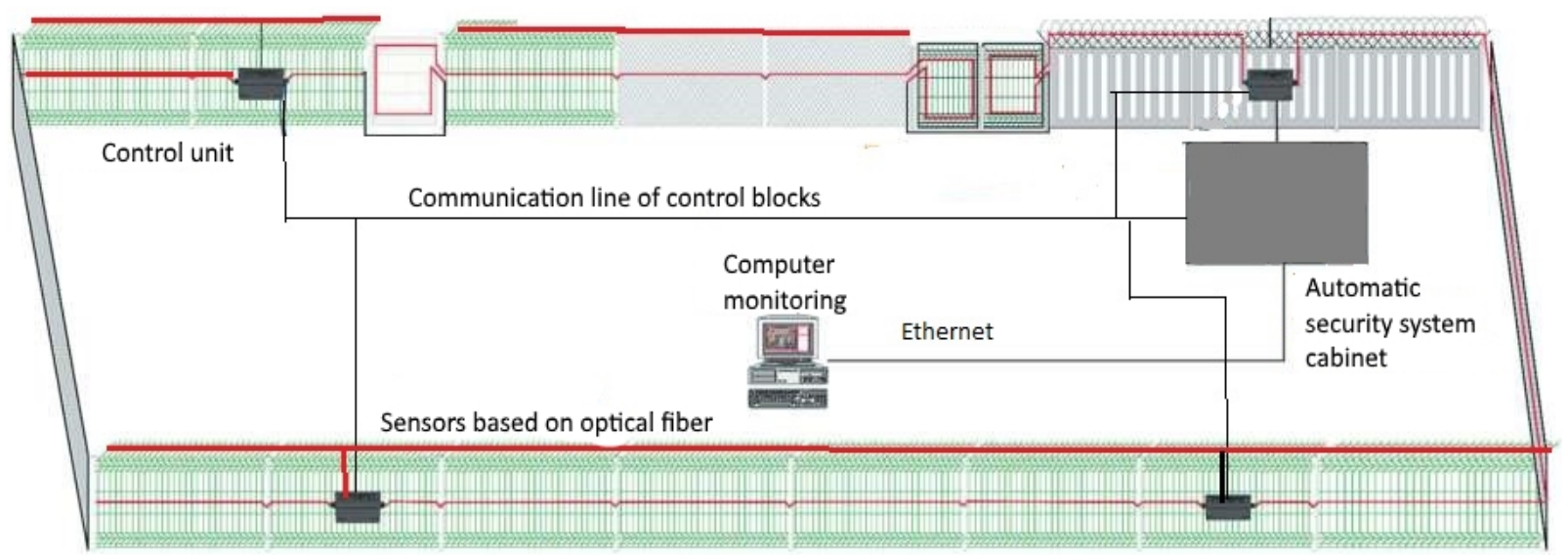

Fig. 1. Scheme of perimeter security alarm installation

Here on the mesh fence there is an optical fiber responsible for monitoring the snacking of the fence. On the top of the fence there is a parallel optical fiber line responsible for controlling climbing through the fence. 


\section{Краткие сообщения}

Consider an algorithm for detecting an intruder, which includes the registration of data and their processing with the generation of an alarm in the event of an intruder entering the protected area.

The signal from the sensor goes to the signal processing unit. The processing of the original signal in the general case consists of several stages. A typical scheme of the signal processing unit using a neural network analyzer is shown in Fig. 2. The scheme, as a rule, includes a signal adaptive filter, a digital signal processor (DSP), and a neural network analyzer is a decision block (intrusion and its type).

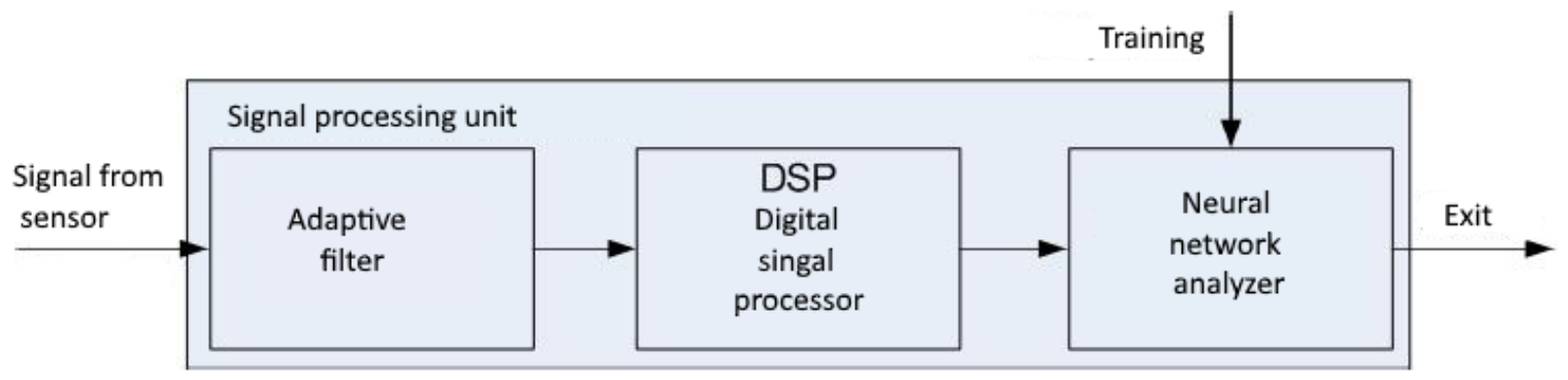

Fig. 2. Scheme of the signal processing unit

Seismic signals and vibrational processes can be described by a universal model: the process is a combination of narrowband components additively mixed with broadband noise. The parameters of the components completely characterize the process. To isolate the narrow-band signal components, the first stage involves the method of extreme filtering. It includes the allocation of signal extremes, the division into alternating components by an extreme filter, the calculation of the parameters of these components (for example, the mean frequency and dispersion in a sliding window), the application of the procedure to the residues formed when the next alternating component is removed.

The components and (or) their parameters allow us to judge the process, to obtain estimates of spectral characteristics, to isolate free and forced oscillations, to form diagnostic features, to substantially simplify the parametric analysis and to reduce its laboriousness, applying it not directly to the signal but to the selected components.

Given the time constraints for the allocation of informative components and decision-making, preference is given to a faster-acting method of extreme filtering.

\section{Decomposition of the signal}

The alternating component can be distinguished by centering relative to the moving average. The simplest method is in which only the extreme values $x_{e i+1}$ are used, where $i=1,2, \ldots, m$. Smoothing is performed by the operator of the form

$$
x_{c i}=0,25 x_{e i-1}+0,5 x_{e i}+0,25 x_{e i+1},
$$

which corresponds to the transmission of data through a digital low-pass filter.

The first, high-frequency component is determined from relation:

$x_{p i}=x_{e i}-x_{c i}$.

The component can be extracted directly from the extremes as follows:

$x_{p i}=-0,25 x_{e i-1}+0,5 x_{e i}-0,25 x_{e i+1}$.

Further transformations of the form (1), (3) are repeated over the component $x_{p i}$.

Then the parameters for all the components $p$ (amplitudes $A_{i}$, frequencies $f_{i}=\frac{n_{t}}{2 \Delta t N}=\frac{n_{t}}{2 T}$, $i=\overline{1, n}$ ), which allow the formation of primary diagnostic features.

Fig. 3 shows the signal at the output of the vibration sensor, and in Fig. 4 - the marked alternating components represented by their extremes for one of the analyzed areas. 


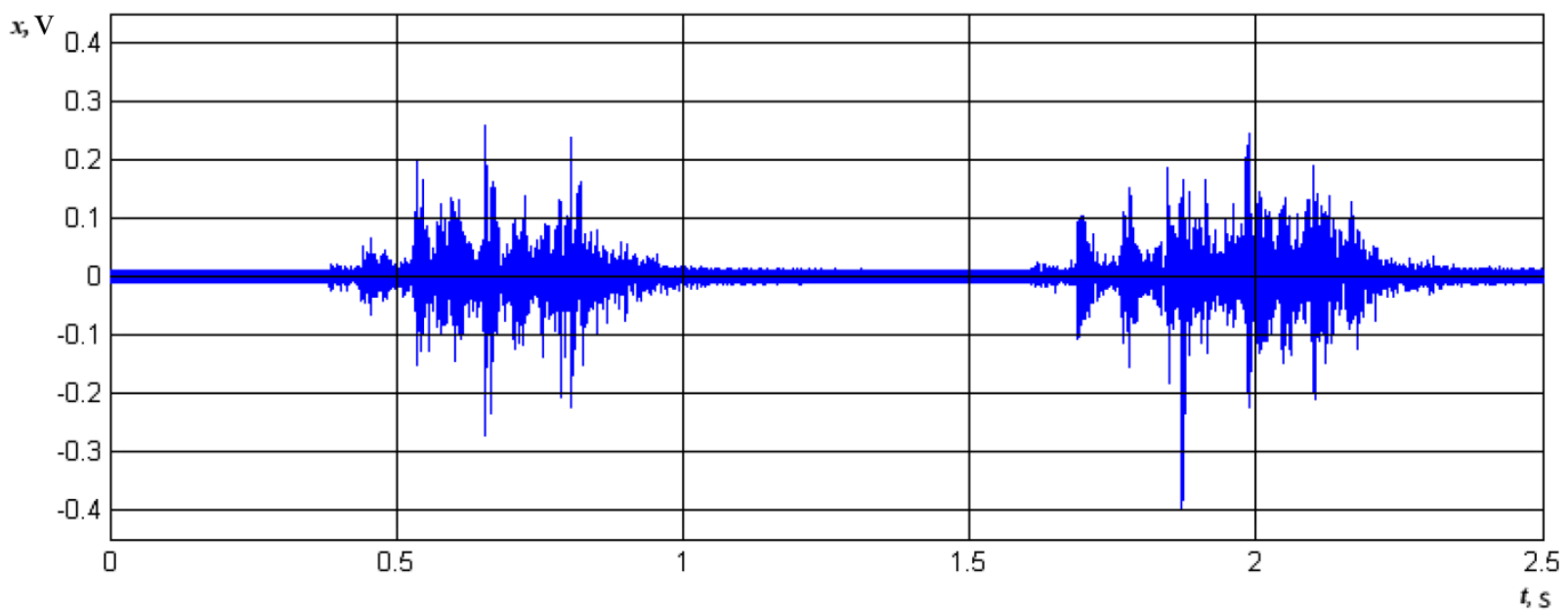

Fig. 3. Signal from the sensor
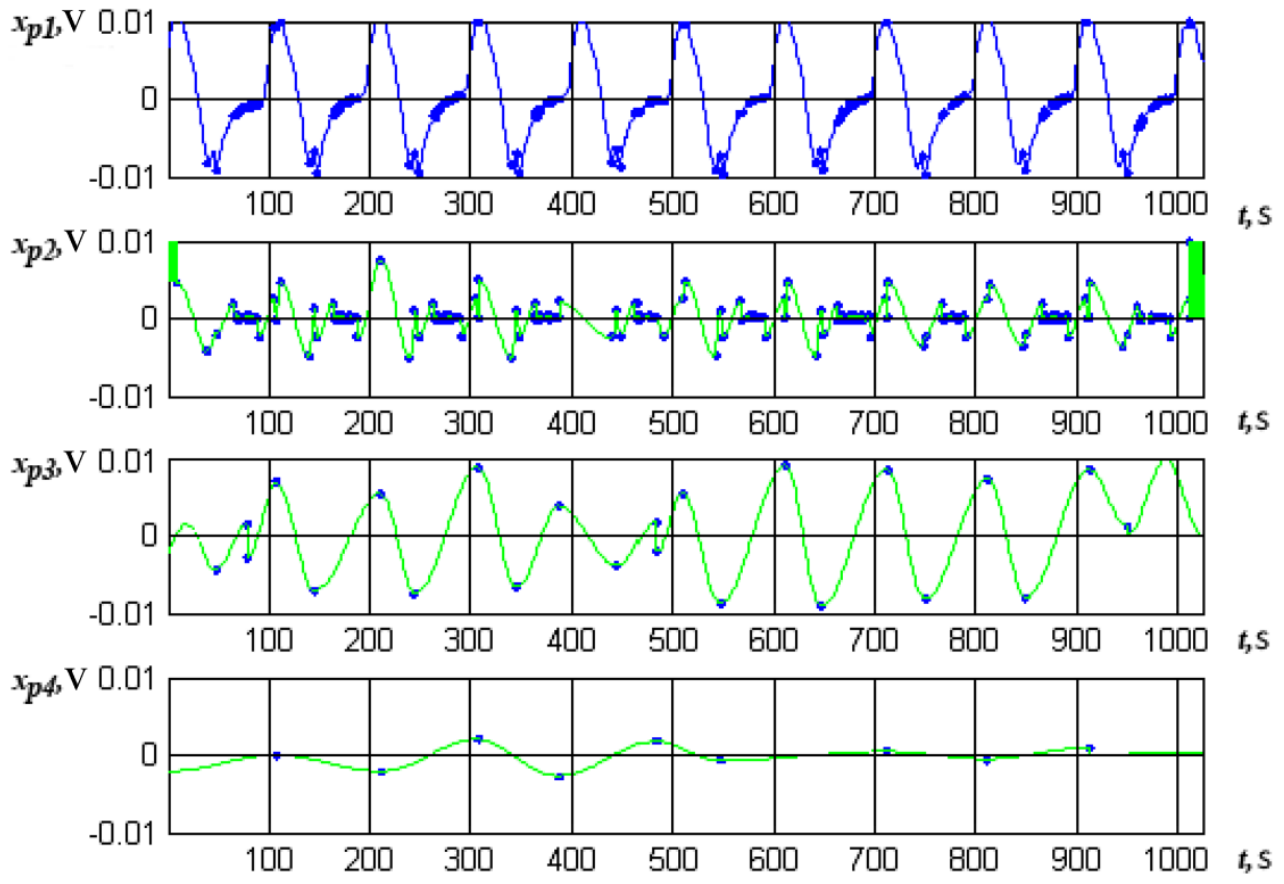

Fig. 4. Variable components of one of the analysis areas

In the transition from seismic noise to the signal generated during the intrusion into the zone of responsibility, the frequency of the components and their amplitude (and, correspondingly, the power) varies significantly. This is illustrated in Fig. 5, where the upper graph shows the signal, and on the second and third - the frequencies and amplitudes $A_{i}$ of the selected components in the sliding window, tied to the beginning of the analysis interval. Here $i=1 \ldots p$, and $\mathrm{p}$ is the number of allocated components. It can be seen that, when detected, there is a decrease in frequency (high-frequency noise is masked by a more powerful signal) and an increase in amplitude.

It is known that signal extrema carry information about the highest-frequency narrow-band component. If we remove (filter out) this part from the signal, we get a smoothed curve, the extremums of which carry information about the next narrowband component. The procedure can be performed until a sequence with alternating extremums is obtained-the lowest-frequency narrow-band component. Thus, an adaptive filtering algorithm is possible.

To separate signals created by the violator from noise and interference, the third and final part of the processing in the Signal Processing Unit performs data analysis based on the principle of the neu- 


\section{Краткие сообщения}

ral network. The use of a neural network provides high reliability of detection at a low level of false positives.
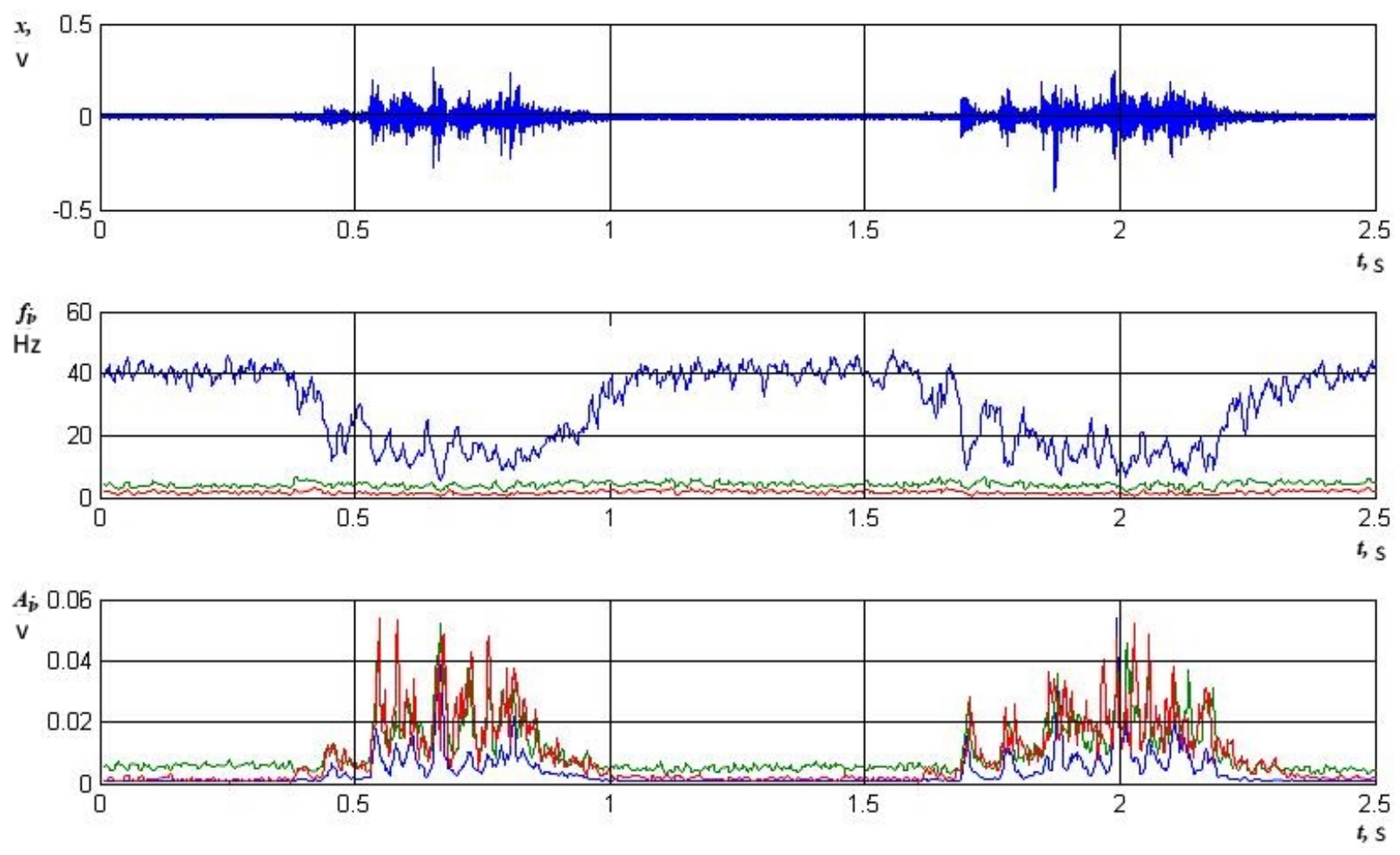

Fig. 5. The signal $x$ and the parameters of the components: $f_{i}, A_{i}, i=1 \ldots p$

\section{Training of neural network}

For the neural network to work, it is required to preteach it. The algorithm for learning a neural network is that the output of the last layer of neurons is compared with the sample of training, and from the difference between the desired and the actual, it is concluded what the neurons of the last layer should be to the previous one. Then a similar operation is performed with the neurons of the penultimate layer. As a result, on the neural network, from the output to the input, a table is made for changing the connection weights. The training of the system is reduced to the work of the algorithm for selecting the weight coefficients, which operates without the direct participation of the operator.

Training involves recording the initial signals from sensors installed on the perimeter. The training of the security system is performed as part of the overall configuration of the system - by adding to the database images of signals that are the result of noise factors and characteristic responses of a particular fence.

So, in Fig. 6, training is provided using a radial-basis network with zero error. The first graph is the desired network output (detection); the second graph is the amplitude of the signal in the vibration protection system; the third schedule is a fixed violation of the perimeter of the protected object. This network was trained on the signal "mesh web". Testing on another kind of impact ("climbing through the fence") showed the correct operation of the detector.

To create, train, and test the network, the Anfisedit editor of the Media environment was used. Network structure: four inputs, one output, number of membership functions - 5 per input, type of the psigmf accessory function. At the input of the network, the parameters of the high-frequency component are given - the mean, minimum, maximum frequencies, and the amplitude-normalized amplitude range in the 3 -second observation interval.

For the data "car driving, group run, car driving", Fig. 6 shows the detection of transport. The output of the network is -1 . 

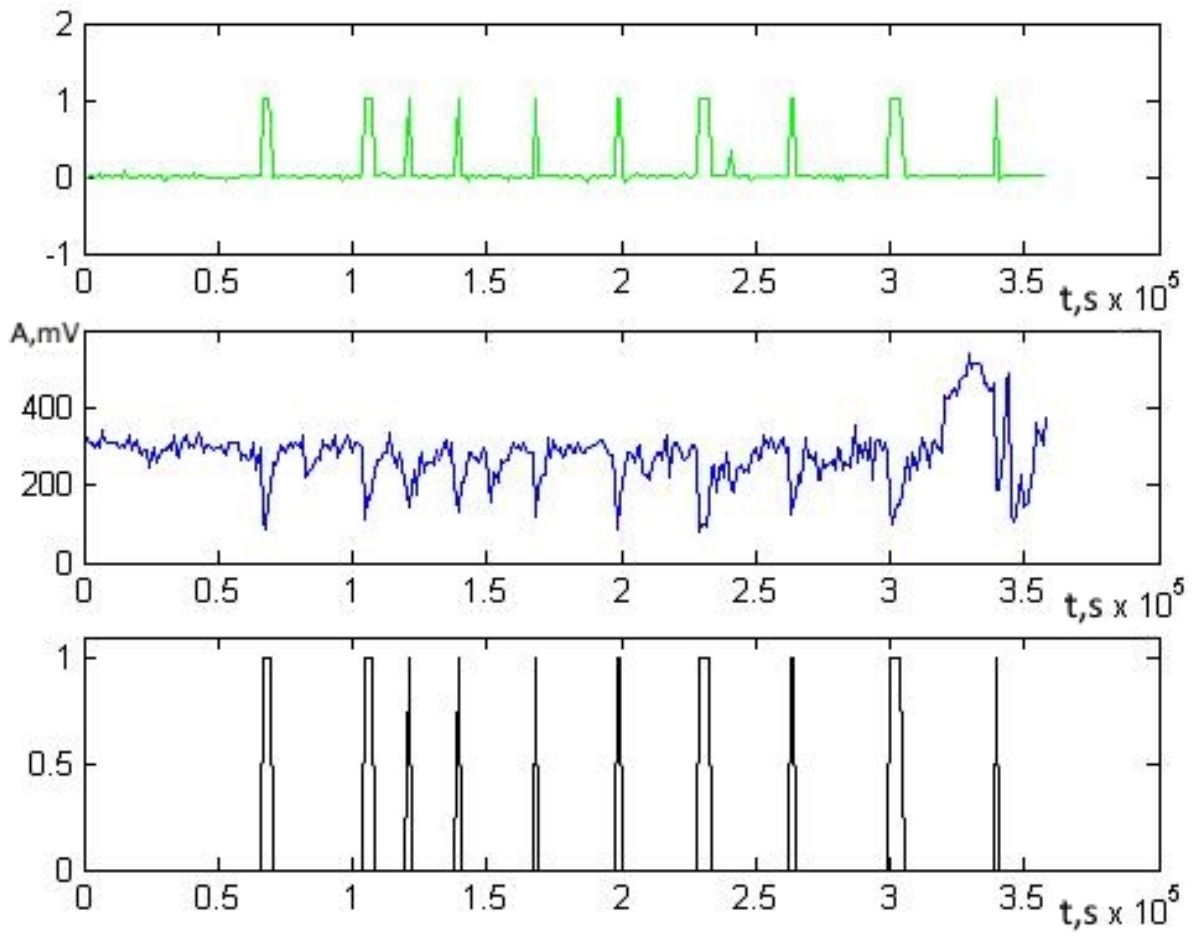

Fig. 6. The operation of a radial-basis network with zero error

\section{Conclusion}

In security alarm systems, a neural network is a computer system, the algorithm for solving problems in which is presented in the form of a network of threshold elements with dynamically tunable coefficients and tuning algorithms independent of the size of the network of threshold elements and their input space. The introduction of neural network structures into the algorithms of the signal processing unit allows to approach the development of security systems with artificial intelligence, to increase the noise immunity of the perimeter security system as a whole. Increases as the average time to false alarm, and the likelihood of detection with subsequent classification of the type of intruder. The security system with artificial intelligence performs the task of detection and recognition automatically, taking into account all the characteristics of the original signal when analyzing. The processing process is much faster and gives a more reliable result. The use of intelligent perimeter security systems does not require operator intervention to analyze alarms and determine signs of a real intrusion or false alarm. As a result, the system itself makes a decision - this signal is a signal of real alarm or interference.

Formation of a system of signs - parameters of alternating components, extracted from the observed signal by an extreme filter, allows solving the problem of detection and classification with the help of neural networks.

\section{References}

1. Ivanov I.V. Okhrana perimetrov [Protection of Perimeters]. Moscow, Paritet Graf Publ., 2000. $196 \mathrm{p}$.

2. Myasnikova N.V., Beresten' M.P. [Extreme Filtering and Its Applications]. Sensors and Systems, 2004, no. 4, pp. 8-11. (in Russ.)

3. Myasnikova N.V., Zenov A.Yu., Ivanova Ye.I. [Detection and Classification of the Intruder at Special Security Facilities]. Tr. mezhdunar. nauch.-tekhn. konf. "Problemy avtomatizatsii i upravleniya $v$ tekhnicheskikh sistemakh [Proc. of Int. Sc.-Techn. Conf. "Problems of Automation and Control in Technical Systems". Penza, PSU Publ., 2011, pp.15-24. (in Russ.)

4. Myasnikova N.V., Beresten' M.P. [Theoretical Bases of Express Analysis]. News of Higher Educational Institutions. The Volga Region. Technical Science, 2006, no. 6, pp. 117-123. (in Russ.)

5. Gruba I.I. Sistemy okhrannoy signalizatsii. Tekhnicheskie sredstva obnaruzheniya [Security Alarm Systems. Technical Means of Detection]. Moscow, Solon-Press Publ., 2012. 220 p. 


\section{Краткие сообщения}

6. Vvedenskiy B.C. Oborudovanie dlya okhrany perimetrov [Equipment for Perimeter Protection]. Moscow, World of Security Publ., 2002. 112 p.

7. Kalan R. Osnovnye kontseptsii neyronnykh setey [Basic Concepts of Neural Networks]. Moscow, Vil'yams Publ., 2001. 291 p.

8. Osovskiy S. Neyronnye seti dlya obrabotki informatsii [Neural Networks for Information Processing]. Moscow, Finances and Statistics Publ., 2002. 344 p.

9. Kolyushinskiy V.A., Smirnov D.A. Neyronnye seti $i$ ikh primenenie $v$ sistemakh upravleniya $i$ svyazi [Neural Networks and Their Application in Control and Communication Systems]. Moscow, Hot Line - Telecom Publ., 2003. 94 p.

10. Voyevodin C.B., Dukhan E.I. [Analysis of Signals From an Intruder in Frequency-Modulated Probing Radiation in SO LVV]. Radio Engineering, 2011, no. 2, pp. 61-65. (in Russ.)

11. Voyevodin C.B., Dukhan Ye.I. [Modeling Signals From a Moving Target in Two-Cable SO LVV]. Materialy VIII Vserossiyskoy konferentsii "Sovremennye okhrannye tekhnologii i sredstva obespecheniya kompleksnoy bezopasnosti ob"ektov" [Materials of the VIII All-Russian Conference "Modern Security Technologies and Means for Ensuring the Integrated Security of Facilities"]. Penza Zarechnyy, 2010, pp. 102-105. (in Russ.)

12. Voyevodin C.B., Dukhan Ye.I., Shmalev T.V. [To the Selection of the Optimal Parameters for the Location of the Radiating Cables of the Detection Means on the Basis of the Outflowing Wave Line]. Materialy V Vserossiyskoy konferentsii "Territorial'no-raspredelennye sistemy okhrany" [Materials of the V All-Russian Conference "Territorial-Distributed Security Systems"]. Kaliningrad, KPP, 2012, pp. 75-78. (in Russ.)

13. Vvedenskiy B.S. [Modern Perimeter Security Systems]. Special Equipment, 1999, no. 3, pp. 34-39; no. 4, pp. 24-29; no. 5, pp. 39-46. (in Russ.)

14. Hunt E. Iskusstvennyj intelekt [Artificial Intelligence]. Moscow, Mir Publ., 1978. 558 p.

15. Tsypkin Yu.A. [Adaptive Methods of Choosing Solutions under Uncertainty]. Automatic Equipment and Telemechanics, 1976, no. 4, pp. 78-91. (in Russ.)

16. Logovskiy A.S. [The Use of Neural Networks to Solve Combinational Problems with a Full Search]. Neurocomputer, 1994, no. 3, 4, pp. 41-50. (in Russ.)

17. Bocharov A.V., Groshev A.S., Zahvatov M.V. [Hardware Implementation of the Accelerator of Neural Computing]. Works of the Universities. Instrument Making, 1995, no. 38, pp. 10-12. (in Russ.)

18. Cygankov V.D. Universal'nyy razum i kvantovyy neyrokomp'yuter. Seriya "Informatizatsiya Rossii v XXI veke" [The Universal Mind and Quantum Neurocomputer. Series "Informatization of Russia in the XXI Century"]. Moscow, SINTEG Publ., 2002. 176 p.

19. Galushkin A.I. Neyrokomp'yutery [Neurocomputers]. Moscow, IPRZHR Publ., 2000. 528 p.

20. Galushkin A.I. Sintez mnogourovnevykh sistem raspoznavaniya [Synthesis of Multilayer Systems for Recognition]. Moscow, Energiya Publ., 1974. 368 p.

21. Vvedenskiy B.S. [Perimeter Security Systems at the IFSEC2000 Exhibition. Part 2]. Special Techniques, 2000, no. 5, pp. 2-12. (in Russ.)

22. Selvarayan A. Fiber Optic Sensor and Their Applications. Indian Institute of Science Publ., $22 \mathrm{p}$.

23. Okosi T. (Ed.) Volokonno-opticheskie datchiki [Fiber-Optic Sensors]. Moscow, Energoatomizdat Publ., 1990. 256 p.

Received 26 December 2017 


\title{
СИСТЕМА АВТОМАТИЧЕСКОГО РАСПОЗНАВАНИЯ ПРОНИКНОВЕНИЯ ЧЕРЕЗ ОХРАНЯЕМЫЙ ПЕРИМЕТР НА ОСНОВЕ ОПТОВОЛОКОННЫХ ДАТЧИКОВ И НЕЙРОННОЙ СЕТИ
}

\author{
А.А. Фартуков, В.П. Шумейко, Л.С. Казаринов \\ Южно-Уральский государственный университет, г. Челябинск, Россия
}

\begin{abstract}
Рассматривается принцип построения программной части блока обработки сигнала охранной системы, который позволит решить задачу обнаружения проникновения через охраняемый периметр при помощи сигнала, поступающего с чувствительного оптоволокна, расположенного на сетчатом заборе. Исследование ведется через рассмотрение таких проблем, как разложение сигнала, полученного с чувствительного оптоволоконного датчика, на составляющие и дальнейшая его обработка сначала для обучения нейронной сети, а потом для анализа ее состояния. Большое место в работе занимает рассмотрение решения, которое позволит сформировать алгоритм построения блока цифровой обработки сигналов с использованием нейронной сети, а также уменьшить с ее помощью количество ложных срабатываний охранной системы, вызванных помехами и внешним воздействием на охранную систему.

Ключевые слова: нейронная сеть, чувствительное оптическое волокно, система безопасности, блок обработки сигналов.
\end{abstract}

\section{Лumepamypa}

1. Иванов, И.В. Охрана периметров / И.В. Иванов. - М.: Паритет Граф, 2000. - 196 с.

2. Мясиикова, Н.В. Экстремальная фильтрация и ее приложения / Н.В. Мясникова, М.П. Берестень // Датчики и системыл. - 2004. - № 4. - C. 8-11.

3. Мясникова, Н.В. Обнаружение и классификация нарушителя на особоважных объектах охраны / Н.В. Мясникова, А.Ю. Зенов, Е.И. Иванова // Проблемы автоматизации и управления в технических системах: тр. Междунар. науч.-техн. конф. - Пенза: Изд-во ПГУ, 2011. - С. 15-24.

4. Мясникова, Н.В. Теоретические основы экспресс-анализа / Н.В. Мясникова, М.П. Берестень // Известия высших учебных заведений. Поволжский регион. Технические науки. - 2006. № 6. - C.117-123.

5. Груба, И.И. Системы охранной сигнализачии. Технические средства обнаружения / И.И. Груба. - М.: Солон-Пресс, 2012. - 220 с.

6. Введенский, В.С. Оборудование для охраны периметров / В.С. Введенский. - М.: Мир безопасности, 2002. $-112 \mathrm{c}$.

7. Калан, Р. Основные концепиии нейронных сетей / Р. Калан. - М.: Вильямс, 2001. - 291 с.

8. Осовский, С. Нейронные сети для обработки информации / С. Осовский. -М.: Финансы и статистика, 2002. - 344 c.

9. Колюшинский, В.А. Нейронные сети и их применение в системах управления и связи / В.А. Колюшинский, Д.А. Смирнов. - М.: Горячая Линия - Телеком, 2003. - 94 с.

10. Воеводин, С.В. Анализ сигналов от нарушителя при частотно-модулированном зондирующем излучении в СО ЛВВ / С.В. Воеводин, Е.И. Духан // Радиотехника. - 2011. - № 2. C. 61-65.

11. Воеводин, С.В. Моделирование сигналов от движущейся иели в двухкабельных СО ЛВВ / С.В. Воеводин, Е.И. Духан // Материалы VIII Всероссийской конференции «Современные охранные технологии и средства обеспечения комплексной безопасности объектов», Пенза - Заречный. - Пенза: Изд-во ПГУ, 2010. - С. 102-105.

12. Воеводин, С.В. К выбору оптимальных параметров размещения излучаютих кабелей средств обнаружения на основе линии вытекающей волны / С.В. Воеводин, Е.И. Духан, Т.В. Шмалев // Материалы V Всероссийской конференции «Территориально-распределенные системы охраньl». - Калининград: КПП, 2012. - С. 75-78. 


\section{Краткие сообщения}

13. Введенский, Б.С. Современные системы охраны периметров / Б.С. Введенский // Специиальная техника, 1999. - № 3. - С. 34-39; № 4. - С. 24-29; № 5. - С. 39-46.

14. Хант, Е. Искусственный интеллект / Е. Хант. - М.: Мир, 1978. - 558 c.

15. Цыпкин, Ю.А. Адаптивные методы выбора решений при неопределенности / Ю.А. Цыпкин // Автоматизачия и телемеханика. - 1976. - № 4. - С. 78-91.

16. Логовский, А.С. Использование нейронных сетей для решения комбиначионных задач при полном поиске / A.С. Логовский // Neurocoтриter. - 1994. - № 3, 4. - P. 41-50.

17. Аппаратная реализация ускорителя нейронных вычислений / А.В. Бочаров, А.С. Грочев, М.В. Захватов и др. // Труды университетов. Приборостроение. - 1995. - № 38. - С. 10-12.

18. Цыганков, В.Д. Универсальный разум и квантовый нейрокомпьютер / В.Д. Цығанков. М.: СИНТЕГ, 2002. - 176 с. - (Серия «Информатизаиия России в XXI веке»).

19. Галушкин, А.И. Нейрокомпьютеры: учеб. пособие для ун-тов / А.И. Галушкин. - М.: ИПРЖР, 2000. - Кн. 3. -528 с.

20. Галушкин А.И. Синтез многоуровневых систем распознавания / А.И. Галушкин. - М.: Энергия, 1974. - 368 c.

21. Введенский, Б.С. Системы охраны периметров на выставке IFSEC2000. Часть 2 / Введенский Б.С. // Специальная техника. - 2000. - № 5. - C. 2-12.

22. Selvarayan A. Fiber optic sensor and their applications / A. Selvarayan. - Indian Institute of Science. $-22 \mathrm{p}$.

23. Волоконно-оптические датчики: пер.с яп. / под ред. Т. Окоси. - М.: Энергоатомиздат, 1990. -256 c.

Фартуков Александр Александрович, аспирант кафедры автоматики и управления Высшей школы электроники и компьютерных наук, Южно-Уральский государственный университет, г. Челябинск; Xaker.cahek@gmail.com.

Шумейко Валентина Павловна, магистрант кафедры процессов и машин ОМД Факультета материаловедения и металлургических технологий, Южно-Уральский государственный университет, г. Челябинск; ShumeikoVP@gmail.com.

Казаринов Лев Сергеевич, д-р техн. наук, профессор, заведующий кафедрой автоматики и управления, Южно-Уральский государственный университет, г. Челябинск; aiu@susu.ru.

Поступила в редакцию 26 декабря 20172.

\section{ОБРАЗЕЦ ЦИТИРОВАНИЯ}

Fartukov, A.A. The System of Automatic Detection of Penetration through the Protected Perimeter Based on Fiber Optic Sensors and Neural Network / A.A. Fartukov, V.P. Shumeyko, L.S. Kazarinov // Вестник ЮУрГУ. Серия «Компьютерные технологии, управление, радиоэлектроника». - 2018. - Т. 18, № 1. - С. 155-162. DOI: $10.14529 /$ ctcr 180119

\section{FOR CITATION}

Fartukov A.A., Shumeyko V.P., Kazarinov L.S. The System of Automatic Detection of Penetration through the Protected Perimeter Based on Fiber Optic Sensors and Neural Network. Bulletin of the South Ural State University. Ser. Computer Technologies, Automatic Control, Radio Electronics, 2018, vol. 18, no. 1, pp. 155-162. DOI: $10.14529 /$ ctcr180119 